\title{
Research on the Dilemma of Street Vendors Management in the City
}

\author{
Xin Zhang \\ Management School \\ China West Normal University \\ Nanchong, China
}

\author{
Pengcheng Zhao \\ Management School \\ China West Normal University \\ Nanchong, China
}

\begin{abstract}
In a long run, governance of city itinerant street vendors is always one of the key problems of urban management. Through the analysis of current administrative troubles, I find that the cruxes of this issue mainly involve following aspects: Large recessive population base, low cost operation, weak organization capability within the group causing "Prisoner's Dilemma", game of all concerned stakeholders, and absence of management. According to our national actual circumstances, some recommendations are made on reducing sources of the traders and perfecting service and supervision of managers as feasible ways to solve real problems.
\end{abstract} trouble

Keywords-street vendors; Prisoner's Dilemma; governance

\section{INTRODUCTION}

The problem of city itinerant traders is an unavoidable topic in the development stages of all countries, and it can be said to be "the inevitable product of social change and development"[1]. As a result, in order to solve this problem effectively, some other countries have summarized and formed a relative maturity management model. For instance, peddlers in France must apply for business license in accordance with law. At the same time, they are also restricted by other related laws; In Thailand, there is a department set up specially for the regulation of the pitching. They are responsible for registration and management. People could merely do business in designated blocks and operate in order. The managing idea of this department: the right to subsistence of these vulnerable groups is more important than other citizens' convenience of walking; It is relatively easy for Korean stall keepers to do this kind of business because the vendor just need to join in "association of Stall owners" and start business after approval [2].

Nowadays, with the continuous development of China's urbanization, the constant expansion of urban construction, pouring rural labors force to the town, large swathes of new citizens, urban villages and peasant workers citizenization have emerged. Nevertheless, it is arduous for majority of them to integrate into formal urban employment mechanism as results of their lack of education, absent employment skills and old ages, giving birth to a large number of locomotive operators. As a result, governing itinerant traders are confronted with a significant test now. The management of urban itinerant traders has tight relation with several big issues in our country including the whole city harmony, accommodation and the people's livelihood $\mathrm{d}$. In our development stage, any relevant difficulty mentioned above must be faced up and enough attentions must be paid to working on solving them. To enable mobile traders to share the fruits of economic and social development, firstly, we are supposed to clarify what the administration dilemma is in our country. Then, based on China's actual situation and combination with successful experiences of other advanced countries and regions, we will gradually explore corresponding management strategies conforming to reality of this kind of business model.

\section{ANALYSIS OF DILEMMA}

\section{A. Large Recessive Population Base and Low Operation cost}

In recent years, as the urbanization deepens in China, the amount of farmers in the city is continuously growing. More people will have to choose self-employment models to make a living on account of limited jobs in city. From the perspective of urban and rural structure, the urban resident population in 2014 is 749.16 million, an increase of 18.05 million compared with the previous year, while the village resident population is 618.66 million, a decrease of 10.95 million. Urbanization rate has reached $54.77 \%{ }^{1}$. Next the circulation of right to use land is now promoted by policy as a replacement of market accelerating population shift from rural to urban. In addition, the continuous expansion of the city, the recession of agriculture itself, and the encroachment on the land by the combination of power and capital also expedite this flow in various degrees from the inside to the outside. Cui Zhanfeng [3] supports that continuous decrease of itinerant traders available in the rural market is caused by the growth of single-line population shift. As the population flow to the counties and cities intensively, it is inevitable for them to trade in city. After the reform and opening up, some elements of market economy started to be introduced into rural areas, which has crippled the influence of country fair hosted regularly. Trading functions of bazaars are absolutely weakened by emerge of some new business circulation organizations especially supermarket in countryside. For one thing, if country fair trade cannot balance the supply and

\section{${ }^{1}$ CHINA ECONOMIC NET}

http://www.ciudsrc.com/new_chengshihualv/gedi/2015-01-20/79954.html 
demand of goods well, and then the interval of regular urban fairs will be shorten and these village fairs will evolve into normal market gradually; for another, as rural trading circulation system and substitutability between circulation organizations are increasingly enhanced, the influence of traditional fixed markets will shrink and a considerable number of mobile traders will be squeezed out and pushed into cities. Not only that, the scattered and disordered chapmen are gradually integrated into "a normal day market" hosted at "fixed time and places" and the disordered trading circulations have been substituted by well-organized circulations little by little, tending to be normal.

Any unit or individual working on business, the main reason of long-term survival is they can get profit through business activities. That is to say, there exists profitable space. If the profit is negative, operators will make a loss; if it is zero, which means profit is equal to total revenue, owners will have balance of payment; if the interest is positive, traders will make profits. Mobile traders, as a general rule, from socially disadvantaged groups without much employment skills and knowledge choose mobile trading as a way of supporting their family. If traders cannot make profits through this kind of business, they will abandon it without doubt. At present, there exist a lot of such kind of people like jobless people, low-income earners and migrant workers in city. Their material life, rights, social reputation, and development prospects are all at disadvantage. In order to survive, this group always tend to choose business which don't need to be invested a lot and through which, they can make profits quickly. Only in this way, can they solve the basic living problems. On one hand, traders don' t need to cost a lot at the very start and money can be got back in a short period. On the other hand confined by old ages and lack of education, capital, and employment skills, they are not qualified in the city regular professional competition. Therefore, based on the theory of rational homo-economics man and the most basic survival needs, itinerant trading is chosen by these vendors preferentially and it will be applied as a major way of earning a living in a long run.

\section{B. Complex Personnel Structure and High Heterogeneity}

Itinerant traders mainly include peasants, urban unemployed people, retirees, veterans and freelancers. Their situations vary: peasants consist of migrant workers, the local landless peasants, as well as young people who need to support the elderly, to take care of their children to school and cannot work outside. On account of adjustment of national land policy, under a series of pressures like survival, children education, healthcare, and the endowment of old people, landless peasants could only choose to move into city and seek opportunities to find jobs. In addition, lack of corresponding survival skills, setting up a stall is the only one and the most direct way for them to earn money. Without doubt, the restriction of business operation certainly will do harm to these traders' life and the social stability. Urban unemployed people mainly include the unemployed and laid-off workers in urban areas. They lost their jobs due to lack of technology and education under the wave of market economy in the 1990s and they have also become an important component of itinerant traders. Facing a lot of
Stress, such as raising children, education, and medical treatment and so on, these people use their free time to sell fruits, vegetables, processed food and other products. This action has met the needs of people living nearby, at the same time, owners can make life subsidiary to their family. What really worries them is the restriction of selling goods on the street and they are often chased by urban management officers. Retired people only occupy a small part, and do not need to worry much about making a living. Stalls for them can be both a way to make money and another amateur "leisure way." Majority of Freelancers are young people, they are in a comprehensive and diverse situation and are not the main component of the trader structure. Some of them are in the accumulation of venture capital, out of personal hobbies, while others treat itinerant trading as a temporary "career" planning.

\section{Weak Organization Capability and the Emerging of "Prisoner's Dilemma"}

At present, most bazaar-type economy in our country is in a state of "Stragglers". Even though there exist some social networks actually, these networks are still fragmented and without integration. Stall operators in some areas are probable fellow villagers or relatives. While some new venders associations which are cross-regional or even nationwide beyond the traditional social networks have not yet appeared. Therefore, lack of effective internal organization and communication, there also exist some problems like "prisoner's dilemma". Due to the limited available area on the street, the trader coming later cannot enter the planning area and have to trade on the trunk road. This has broken the rules. The consumption in an area is limited, and the traders who disobey the rules indirectly lead to the economic loss of the traders who operate under the rules. Lack of the punishment mechanism in the group, following the rules means the economic loss while going against rules is probably beneficial. Therefore, people start to do business on the trunk road one after another.

Prisoner's dilemma indicates that the best choice for one is not the best for the group. In terms of the rules that traders can only sell in the planning area, some people abide by them and some people do not comply with them. Besides, there are also some people who want to comply, but have to go against the regulations. Why is there such a dilemma? It is because everyone in this group is a rational actor and they clearly know that it is futile for them to give priority to the interests of other traders or even the whole group. What's more, this profitless and selfless behavior is treated with no praise[4].Therefore, why people are racing to sell on the streets with stalls is not difficult to be understood.

\section{The Game between Stakeholders}

Owing to absence of supervision and market entry certification system, mobile traders have caused a series of social problems including traffic congestion made by occupation of road, infringement upon citizen's legal property and health as a consequence of unqualified products and the violation of environmental right resulting from market mess. In the meantime, the business also has a terrible effect on comprehensive city governance, traffic 
order and city appearance. All I mentioned above has suggested that to the stalk keepers, it is quite essential to regulate their business activities through corresponding laws and cannot just let it be. According to the social management and vendors governance model built up by the new public service theory, will "service" rather than "regulation" in the first place [5]. Government departments responsible for city management are supposed to create and maintain nice human living environment and strive to increase the citizen's recognition of government by doing so. However, there must be some cost when they put it into practice-managing vendors and persuading citizens. Based on "economic man" mind, vendors tend to operate maximally freely. Nevertheless, their business activities are constrained by city management. Consequently, managing cost will increase as governance is enhanced more deeply and widely. Generally speaking, although citizens are willing to enjoy beautiful city environment, they also benefit from mobile trading feel sympathetic to those traders. Therefore, under certain conditions, the demand of city administration is not so high.

In the view of public choice theory, Wang Yaxin [6] supports that the management of urban mobile traders depends on equilibrium between the demands of traders and stakeholders. At present, the government and the city residents are both enjoying the convenience and bearing the adverse effects of traders at the same time. Whereas these two different factors have failed to have a decisive influence on making their final decisions whether to cancel the business. There is a game between governors, traders, and inhabitants. We have to admit that itinerant trading has brought citizens more convenience in their daily life and to a certain extent, this kind of business has doubtlessly solved employment issues of people at the bottom and made contributions to social stability [7]. However, the bad effects on traffic and city appearance are becoming distinctly inevitable with its negative externality. In this limited area, when space for business is so large that trading has influenced peoples' daily life, people living here will become angry and bring their dissatisfaction to government's attention to the government. Of course, as managers, governors are responsible for solving this problem and maintain the order of public environment. However, the government departments get into a dilemma more often than not in the process of governance. If officials handle it severely, then they will be challenged by traders and other social groups, and also accused of not being humanistic enough, while easing managerial policy will be blamed for irresponsibility by the public.

\section{E. Absence of Governance from Management Subjects and Single Governance Method}

Recently, in terms of mobile traders, the regulations are mainly prohibitive and limitative and basically, the reasonableness of their existence is not recognized. Accordingly, administration methods of city governors mainly include driving and banning which is barely satisfactory. On one side, urban inspector governs stalk keepers in accordance with related laws and regulations; on the other side, to relieve life stress, these mobile vendors from the bottom of society have no choice but to go against city management or even conflict with inspectors fiercely. Even though a majority of mobile traders living in the lowest strata of city are poor and vulnerable, they still have one right exactly same and equal with other people in city. That is the right to live.

There are two types of management principals discussed here: "Endogenous type" and "Adventive type". "Endogenous type" refers to the managerial subject from the inside of itinerant traders; "Adventive type" refers to the managerial subject from outside of the these business groups. Ferdinand Tönnies [8] wrote in his book, "gemeinschaft und gesellschaft: grundbegriffe der reinen soziologie", that any relationship is the unity of the majority, or the majority of the unity. It is made up of promotion, convenience, and effectiveness and these elements interact with each other. And then, Group formed through this positive relationship is a kind of combination, only if all of these elements (people or things) play a unitive role internally and externally. Governors and the governed should make up an active organization and both two parties work hard together to accelerate the whole group's harmony development. However, at present, some relevant departments simply "plan" the area available to be operated, and some of these areas are even supplied by the third party ---nongovernmental organizations. And traders have to pay certain "land fee" or " management fee" if they want to enter these areas to operate. Therefore, as a matter of fact, the itinerant trading now is a self-supporting model in a certain extent. In terms of management, there is no leader inside and also no rule maker from outside resulting in no any incentive and punitive measures. As a result, collective action dilemmas are inevitable in this situation.

\section{SUGGESTIONS}

\section{A. To Reduce the Source of Traders}

In terms of main source of mobile traders, in education: the government is supposed to strengthen the training of continuing education on knowledge and employment skills and accelerate the community education. With the qualification of practitioners at lower layers enhanced, they can get formal social jobs again. In addition, some measures on protection of the children's education in this group are also required to be taken by the officials, to prevent the "Intergenerational Transmission of Poverty". In social security: More advanced and widespread nationwide network of social security is required to be established. For landless peasants caused by house demolition and land expropriation, people in charge ought to take subsequent ability to survive and develop of the peasants in this group into account and do not pay them lump-sum compensation at low prices because the land is the most basic social security for them, and government must take corresponding measures on employment and social welfare system to help those without land [9].

\section{B. To Improve Service and Supervision of Management Subjects}

The subject of management could be both "Endogenous type" and "Adventive type". A group of people, represented 
by Liu Lingling [10] holds an idea that trade association of stall-keeper and peddler should also play a role of supervision to some extent and help stall keepers find out problems in time and handle them within the group realizing autonomy and self-management. Under the management of "Adventive type", directors can bring in the third institution--NGO (non-governmental organization). However, it is of great necessity for government to monitor and measure NGO and decide whether this organization is definitely qualified to be the leading subject. Firstly, rules should be made and for the sake of successful implementation, the reward and punishment mechanism ought to be formulated accordingly. Without doubt, Rule-breakers will be punished and contributors benefitting the whole group in a long term will be awarded. Finally, a virtuous service and supervision mechanism is completed. Secondly, mobile place of business can be divided into three parts including prohibited area, control region, and guidance area. All of these areas are managed separately. In the prohibited area, any mobile business without license is not allowed here; in control region, the scope and time of business are under strict restriction through appropriate control; For example, setting up stalks at crossroads during peak commuting hours is forbidden. In guidance area, the hours could be extended and scale of operation is expanded to some extent, even though they are still limited; Last but not the least, mobile traders should also behave within some restraint. On one hand, market access system must be brought into force, although practitioners of mobile business are mainly from the bottom of society and they need to be cared about. On the other hand, this kind of business serves masses of consumers whose right to life and health should also be protected. As a consequence, there ought to be certain limitation of market admittance to regulate the business without license. For example, physical examination results of traders engaging in food production and processing are demanded to be provided. That means only healthy people could serve food to customers.

\section{REFERENCES}

[1] Sharit K. Bhowmik. Street Vendor in Asia [J]. Economic and Political Weekly, 2005(22):2256-2264.

[2] Liang, Bo. The enlightenment of related managing experience from foreign cities for China $[\mathrm{J}]$. China Price.

[3] Cui, Zhanfeng. Reflection on mobile vendors' root, essence and governance[J]. Management world.(October, 2013)

[4] Mancur Lloyd Olson. The logic of collective action [M].Shanghai: Truth \& Wisdom, Pres, 2014, P73-74.

[5] Janet V. Denhardt, Robert B. Denhardt. The new public service: serving, not steering $[\mathrm{M}]$. Beijing: China renmin university press, 2010:100-111.

[6] Wang Yaxin. Floating Vendors Management in the City under the Theories of Public Option[J]. Contemporary economic and management. (August, 2009):77-80.

[7] Keith Hart. Informal Income Opportunities and Urban Employment in Ghana[J]. The Journal of Modern African Studies, 1973(1): 6189.

[8] Ferdinand Tönnies. Gemeinschaft und Gesellschaft: Grundbegriffe der reinen Soziologie[M]. Beijing: Peking University Press, 2010.

[9] Sun, Liping. Cleavage: Chinese Society Since 1990s [M].Beijing: social sciences academic press(CHINA):P2-3(2003).
[10] Liu, Lingling. Management Strategy on External Analysis of Mobile Vendors-Taking Beijing as an Example[J]. Technoeconomics \& managementresearch.(May, 2014) 